\title{
The Optimal Monetary Instrument for Prudential Purposes
}

By C.A.E. Goodhart*, P. Sunirand ^ and D.P. Tsomocos`

\begin{abstract}
$\underline{\text { Abstract }}$
The purpose of this paper is to assess the choice between adopting a monetary base or an interest rate setting instrument to maintain financial stability. Our results suggest that the interest rate instrument is preferable, since during times of a panic or financial crisis the Central Bank automatically satisfies the increased demand for money. Thus, it prevents sharp losses in asset values and enhanced asset volatility.
\end{abstract}

Keywords: interest rates, monetary base, bank capital, financial stability, monetary policy

JEL Classification: D58, E44, G28

\footnotetext{
* Financial Markets Group, London School of Economics.

^ Financial Markets Group, London School of Economics.

` Saïd Business School and St. Edmund Hall, University of Oxford.

Phone:+44-1865-288 932, Fax: +44-1865-288 805

E-mail: dimitrios.tsomocos@sbs.ox.ac.uk
} 


\section{Introduction}

The monetary authorities can, in principle, choose either a monetary (base) target, or set a nominal interest rate. Virtually all studies of these two alternatives have, heretofore, reviewed this choice in the context of macro-monetary policy, in particular for the objectives of achieving price (and output) stability. Milestones along this route include Poole (1970), Sargent and Wallace (1975) and more recently McCallum (1999 and 2005), and Woodford (2006). ${ }^{1}$

But the achievement of macro-policy stability is only one of the objectives of the monetary authorities. A second core purpose is to maintain systemic stability, to prevent panics and contagious collapses of the banking and payments' systems. Just as the choice between adopting a monetary base or an interest rate setting instrument may impinge on macro policy stability, so that same choice may also have implications for a Central Bank's ability to maintain systemic stability. The purpose of this paper is to explore those latter implications.

The basic intuition, why an interest rate instrument is preferable for this latter purpose, is almost trivially simple. A panic, or crisis, involves a loss of confidence, with sharp losses in asset values and enhanced asset price volatility. In these conditions there will be a marked increase in the demand for safe, liquid assets, for broad money if confidence in bank solvency survives, for base money if it does not.

\footnotetext{
1 The debate has circled, rather like Denis Robertson's hunted hare (in Lectures on Economic Principles, 1959) from espousing monetary targets, as having better stabilisation properties, at least in theory, in the 1970s to the present preference for setting interest rates directly to hit an inflation target, (without any reference to the monetary aggregates), since this latter avoids the instability (error shocks) inherent in the velocity (demand for money) function. It is not our purpose here to comment on this literature.
} 
If the Central Bank holds interest rates pegged, it will quasi-automatically satisfy that increased demand for money. If it holds the monetary base constant, that extra demand for money will drive up interest rates, exacerbating asset price losses and worsening the crisis.

In particular, changes, especially declines, in asset markets can be sudden, and that can drive sharp swings in sentiment/confidence. Such fluctuations in confidence are latent variables, difficult to observe with any accuracy. So a policy stance that quasiautomatically offsets them is especially valuable. Moreover, panics/crises can emerge rapidly out of a blue sky, as in many Asian countries in 1997/98 and from the US subprime mortgage market in mid 2007, or from seemingly extraneous events, as in Iceland in May 2006, or the Shanghai stock market in February 2007. Again an instantaneous quasi-automatic policy response can be better than waiting for a Committee decision.

One reason why the initial Sargent and Wallace (1975) preference for using a monetary aggregate as the authorities' instrument was later abandoned is that inflation is a relatively slow-moving variable, reasonably accurately observed at frequent intervals. So, despite the fact that using the monetary base as instrument also provides quasi-automatic stabilisation properties for the real economy, there is usually plenty of time and of information to adjust interest rates directly to drive forecast inflation back into line with target inflation, while remaining within the periodic cycle of policy committee meetings. When dealing with potential financial crises, however, the relevant time frame is often much more immediate, and information on market 
moods much less concrete. In such circumstances quasi-automatic stabilising properties become much more valuable.

We do not claim that this simple argument is original; it is too patently self-evident for that to be true, though it is not all that frequently made. ${ }^{2}$ What we do claim is that we are the first, in this paper, to present a rigorous, rational expectations, general equilibrium model in which the alternative effects on systemic stability of the choice between a monetary aggregate and an interest rate policy can be calibrated in quantitative terms.

In the next Section, Section II, we present our basic model. This is not new in this paper. It is the model that we have been developing for several years, in a number of papers, (Goodhart et al., (2004, 2005a and b, 2006a and b) and Aspachs, Goodhart et al. (2007)). Indeed parts of Section II follow directly from Aspachs, Goodhart et al., (2007), so that readers do not have to go to a separate site to follow what is going on. Then in Section III we calibrate the effect of a variety of shocks on the model in identical circumstances, except that in one case the policy instrument is a (temporarily) pegged money stock, while in the other it is a (temporarily) pegged interest rate. We demonstrate that the effects on key variables in the financial system of most such shocks are far more destabilising when the money stock is held constant,

2 One recent example where it is made comes in a paper by V. Gaspar (2006), who writes (pp 7/8):-

"A corridor system for monetary policy implementation provides a very effective framework to ensure central bank's control over daily interest rates. It does so while providing an elastic currency, in other words by accommodating economic agents' demands for payments media in a way compatible with the smooth functioning of transactions mechanisms in the economy. A corridor system includes a marginal lending facility that fulfils the principles of the classical lender of last resort doctrine. Therefore, the corridor system for monetary policy implementation subsumes the classical lender of last resort function. It ensures it either through open market operations or through the automatic functioning of the marginal lending facility (or both). Hence, such framework contributes to financial stability, in accordance with the general principle of an open market economy, with free competition." 
than when the interest rate is pegged. Section IV indicates some qualifications, indicates avenues for further research, and concludes.

\section{Description of the model ${ }^{3}$}

The model incorporates heterogeneous banks and capital requirements in a general equilibrium model with incomplete markets, money and default. It extends over two periods and all uncertainty is resolved in the second period. Trade takes place in both periods in the goods market. In the first period agents also borrow from, or deposit money with banks, mainly to achieve a preferred time path for consumption. Banks also trade amongst themselves, to smooth out their individual portfolio positions. The Central Bank intervenes in the interbank market to change the money supply and thereby set the interest rate. Capital adequacy requirements (CARs) on banks are set by a regulator, who may, or may not, also be the Central Bank. Penalties on violations of CARs, and on the default of any borrower, are in force in both periods. In order to achieve formal completeness for the model, banks are liquidated at the end of the second period and their profits and assets distributed to shareholders. Figure 1 makes the time line of the model explicit.

\footnotetext{
3 For an extensive description of this variant of the model see Goodhart et al. (2005).
} 


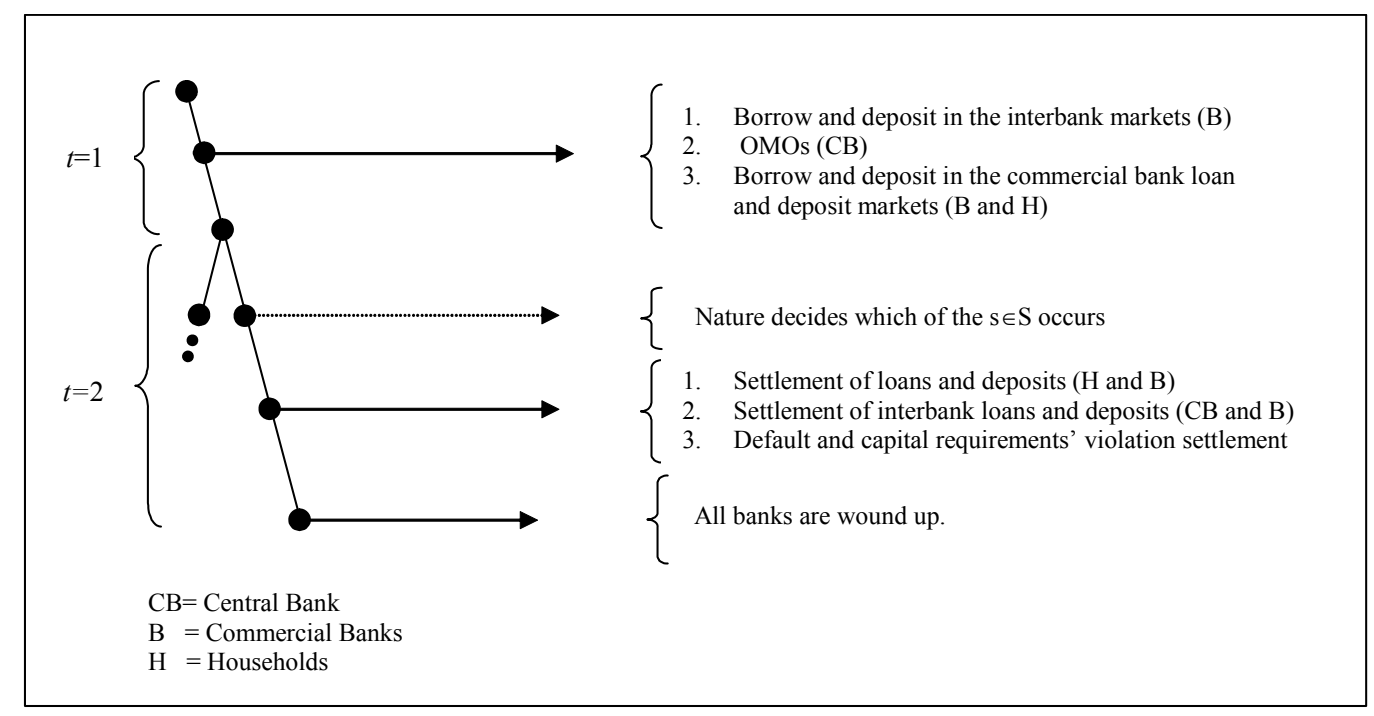

Figure 1: The time structure of the model

In the first period trades by all agents take place against a background of uncertainty about the economic conditions (the state of nature) that will prevail in the second period. Agents are, however, assumed to have rational expectations, and to know the likelihood of good and bad states occurring when they make their choices in period one. In period two the actual economic conjuncture is revealed and all uncertainty is resolved.

The model incorporates a number of distinct, i.e. heterogeneous, commercial banks, (in this calibration, three $(\gamma, \delta, \tau)$ ), each characterised by a unique risk/return preference and different initial capital. Since each bank is, and is perceived as being, different, it follows that there is not a single market for either bank loans or bank deposits. In addition, we introduce limited access to consumer credit markets, with each borrowing household (households $\alpha, \beta$ and $\theta$ ) assigned (by history and custom) to borrow from a predetermined bank. There is also a single (wealthy) household ( $\Phi)$ who places deposits with the banks. This feature allows for different interest rates 
across the commercial banking sector. In sum, multiple credit and deposit markets lead to (very slightly) different loan rates among various banks and to endogenous credit spreads between loan and deposit rates.

Individual non-bank agents are also assumed to differ in their risk attitudes and hence in their preferences for default. We model the incentive for avoiding default by penalising agents and banks proportionately to the size of default. Banks that violate their capital adequacy constraint are also penalised in proportion to the shortfall of capital. Both banks and households are allowed to default on their financial obligations, but not on commodity deliveries.

Our specification in this example of the banking sector is based on a system comprising the seven largest UK banks: Lloyds, HSBC, Abbey National, HBOS, Barclays, Royal Bank of Scotland, and Standard Chartered; though the same modelling approach could, in principle, be applied to the banking system of any other country, or region. Banks $\gamma$ and $\delta$ can represent any two of these individual banks, whereas bank $\tau$ represents the aggregation of the remaining banks. In our calibration exercises, banks $\gamma$ and $\delta$ will be chosen specifically to represent two of these actual UK banks. However, for data confidentiality reason, we will not reveal their identities.

All banks in the model, $\mathrm{b} \varepsilon \mathrm{B}=\{\gamma, \delta, \tau\}$, are assumed to operate under a perfectly competitive environment (i.e. they take all interest rates as exogenously given when making their optimal portfolio decisions). The structure of their balance sheets is given below: 


\begin{tabular}{|l|l|}
\hline Assets & Liabilities \\
\hline Loans to agents & Deposits from Mr. $\Phi$ \\
Interbank deposits & Interbank borrowing \\
Market book & Equity \\
& Others \\
\hline
\end{tabular}

We assume that all banks endogenise their decisions in the loan, deposit and interbank markets. ${ }^{4}$ The remaining variables are treated as exogenous. ${ }^{5}$ We further assume that banks can default on their financial obligations, subject to default penalties set by the regulator. Thus, by varying the penalties imposed on default from 0 to infinity, we can model $100 \%$ default, no default or an equilibrium level of default between 0 and $100 \%{ }^{6}$ At first sight, this 'continuous' default rate approach may seem problematic since in reality banks either repay in full at the due date or are forced to close down. However, we interpret a bank's default rate in our model as a probability that such bank chooses to shut down, and hence in the short run to default completely on its financial obligations. Therefore, a bank's decision to increase its default rates is isomorphic to its decision to adopt a riskier position in pursuit of higher expected profitability. With a large number of agents, as in a competitive equilibrium, conditions where everyone defaults on, say, $5 \%$ of their liabilities are equivalent to those where $5 \%$ of agents default on all their debts. This, however, is not the case when there are only a few agents in a concentrated field. If there are, say, only two agents in the field, and their failures are independent of each other, then in $0.25 \%$ of all cases there will be $100 \%$ default, in $9.75 \%$ of cases $50 \%$ default, and in $90 \%$ of

\footnotetext{
4 The modelling of the banking sector follows Shubik and Tsomocos (1992) and Tsomocos (2003a,b).

5 As explained in Goodhart et al. (2005), we cannot endogenise banks' decisions on market book or equity. Since the model has two states in the second period and one unconstrained asset, the interbank market investment, adding another unconstrained asset would make the markets complete.

6 This modelling of default follows Shubik and Wilson (1977).
} 
cases no default, which is clearly vastly differently from a $5 \%$ default rate amongst a large number of agents.

In most countries banking is a concentrated service industry. Moreover, reputational effects and cross-default clauses, amongst other things, mean that banks cannot default partially and remain open. If they cannot meet their payment obligations, (except under force majeure as in 9/11), they have to close their doors. Except when such closed banks are tiny, such closure does not however, in almost all cases, then turn into permanent liquidation. Effectively almost all banks are restructured, often via a 'bridge bank' arrangement, and shortly re-open, with the extent of short-fall of assets distributed amongst the various creditors, (the 'haircut' in the American phrase), the shareholders and taxpayers depending on the deposit insurance arrangements, bank bankruptcy laws and political pressures. In this latter sense, even though the banking system is concentrated, and banks have to close when they cannot meet due payments, it is perfectly valid to assess strategies as bringing about possible conditions in which a bank defaults by, say, $5 \%$ to all depositors, because that would be the effective loss of funds, or haircut, in the event of a bad state of the world.

Finally, as in Bhattacharya et al. (2007), we make the simplifying assumption that banks' default rates in the deposit and interbank markets are the same, i.e. that banks are restricted to repay all their creditors in the same proportion.

Banks can also violate their capital adequacy requirement, subject to capital requirement violation penalties set by the regulator. In principle, each bank's effective capital to asset ratios may not be binding, (i.e. their values may be above the 
regulator's requirement), in which case they are not subject to any capital requirement penalty. However, in our calibration exercises, we assume that each bank wants to keep a buffer above the required minimum, so that there is a non-pecuniary loss of reputation as capital declines; in this sense the ratios are always binding. Put differently, we assume that banks' self-imposed ideal capital holdings are always above the actual values of all banks' capital to asset ratios. Given this assumption, we can rule out corner equilibria and therefore focus our analysis entirely on well-defined interior solutions whereby banks violate their enhanced capital requirements. We assume that penalties are linear as capital declines from its ideal level. ${ }^{7}$

The calibration exercises presented in Section III are based on the data of UK banks at the end of 2002. At that point in time, bank $\delta$ is a net lender whereas banks $\gamma$ and $\tau$ are net borrowers in the interbank market. ${ }^{8}$ The optimisation problem of banks, as well as the rest of the model, is described in more detail in Goodhart et al. (2005). The model used here has a slightly different specification of the reduced-form equations describing the behaviour of the household sector.

III. Calibration of the Comparative Effects of the Choice between the two Alternative Operational Instruments

The methodology for undertaking this calibration has already been published in Goodhart, Sunirand and Tsomocos (2005). The monetary base is, of course, the dual

\footnotetext{
7 In practice, there will be some non-linearity as capital falls below its required minimum, but this is just too complex to model at this stage.

8 As noted earlier, we have chosen banks $\gamma$ and $\delta$ to represent specifically two of the seven largest UK banks in our calibration exercise. Bank $\tau$ then represents the aggregation of the remaining five banks.
} 
of the (interbank) interest rate in this model in the sense that for any policydetermined shift in base money (interest rate), there is a unique equivalent adjustment in the interest rate (stock of base money). We shall start below (Section IIIa) by examining an example when the Bank of England engages in expansionary monetary policy. However the response of the system to an outside shock of differing kinds varies greatly depending on whether the Bank holds the monetary base or the nominal interest rate constant. We continue then in the remainder of Section III to explore such differing systemic reactions.

III (a) An expansionary monetary policy

We first analyse the case when the Bank of England engages in an expansionary monetary policy. As expected, we found that the result is exactly the same regardless of whether the Bank uses its base money or the interbank rate as its monetary policy instrument (i.e. the Bank increases its base money and allows the interbank rate to be determined endogenously, produces the same result as the case when the Bank decreases the interbank rate and lets its base money adjust endogenously). We summarise the percentage changes in the values of certain key variables in response to an increase in the Bank's base money from 69.28 to 71.28 trillion pounds (approximately 2.9\%) in table I. As can be seen from the table, the interbank rate decreases by $0.8 \%$. Given a lower rate of return on interbank market investment, other things constant, bank $\delta$ invests less in this market (recall that bank $\delta$ is the net lender in this market). It demands less funds from the deposit market and it increases its loan supply to its nature-selected customer, Mr. $\beta$. This portfolio adjustment of bank $\delta$ produces a negative pressure on both its deposit and lending rates. Unlike bank $\delta$, 
banks $\gamma$ and $\tau$ are the net borrowers in the interbank market. Thus they respond to a lower cost of interbank borrowing by reducing their demand for deposits, borrowing more from the interbank market, and lending more to their nature-selected customers, Mr. $\alpha$ and $\theta$, respectively. This, in turn, causes a negative pressure on these two banks' deposit and lending rates.

All banks rationally anticipate that their greater credit extension would increase the overall supply of credit in the economy, thus causing the probability of household default to decline. This is because greater aggregate credit supply not only directly increases households' liquidity but also increases their income in both states of the subsequent period. As can be seen from table I, GDP increases by $0.05 \%$ in both states. Thus, the expected rate of return from extending loans increases for all banks, implying that their willingness to supply more credit rises even further.

Given higher expected GDP in both states, every household borrower (i.e. Mr. $\alpha, \beta$, and $\theta$ ) demands more loans, imposing a positive pressure on the lending rates offered by their respective nature-selected banks. However, this 'crowding-out' effect is dominated by the corresponding negative pressure from greater credit supply by all banks. Thus, we observe that their lending rates decline $(0.9 \%$ for bank $\delta$, and $1 \%$ for banks $\gamma$ and $\tau$ ). We also find that the deposit rates offered by all banks decrease (i.e. $0.9 \%$ for bank $\delta$ and $0.8 \%$ for banks $\gamma$ and $\tau$ ). This is not only because all banks demand less funds from the deposit markets but also because Mr. $\varphi$ responds to higher expected GDP by supplying more deposits to every bank. 


\begin{tabular}{|c|c|c|c|c|c|c|c|c|c|c|c|c|c|}
\hline \multicolumn{14}{|c|}{$\begin{array}{l}\text { Table I: \% changes in key variables given a positive shock in base money } \\
\text { (Central Bank sets its base money) }\end{array}$} \\
\hline & Int & restF & ites & & & & & & & & & & \\
\hline & $r_{d}^{b}$ & $r^{b}$ & $\rho$ & $\pi_{i}^{b}$ & $\pi_{i i}^{b}$ & $e_{i}^{b}$ & $e_{i i}^{b}$ & $k_{i}^{b}$ & $k_{i i}^{b}$ & $v_{i}^{b}$ & $v_{i i}^{b}$ & $\mathrm{GDP}_{i}$ & $\mathrm{GDP}_{\mathrm{ii}}$ \\
\hline Bank $\delta$ & -0.9 & -0.9 & \multirow{3}{*}{-0.8} & $\frac{-4}{10^{3}}$ & $\frac{-5}{10^{3}}$ & $\frac{-3}{10^{4}}$ & $\frac{-2}{10^{4}}$ & -0.1 & -0.1 & $\frac{-6}{10^{3}}$ & 0.01 & \multirow{3}{*}{0.05} & \multirow{3}{*}{0.05} \\
\hline Bank $\gamma$ & -0.8 & -1 & & $\frac{-9}{10^{3}}$ & -0.01 & $\frac{-2}{10^{3}}$ & $\frac{-5}{10^{3}}$ & -0.1 & -0.2 & $\frac{-2}{10^{3}}$ & $\frac{3}{10^{3}}$ & & \\
\hline Bank $\tau$ & -0.8 & -1 & & $\frac{-2}{10^{3}}$ & $\frac{-2}{10^{3}}$ & $\frac{-3}{10^{4}}$ & $\frac{-3}{10^{4}}$ & -0.1 & -0.1 & $\frac{-1}{10^{3}}$ & $\frac{4}{10^{3}}$ & & \\
\hline
\end{tabular}

$x_{i} / x_{i i}$ represents the value of variable $\mathrm{x}$ in (i) the good state and (ii) the bad state

$r_{d}^{b} \quad$ is the interest rate offered on deposits by each bank

$r^{b} \quad$ is the interest rate charged on loans by each bank

$\pi^{b} \quad$ is the profit earned by each bank

$e^{b} \quad$ is the volume of capital held by each bank

$k^{b} \quad$ is the capital to asset ratio of each bank

$v^{b} \quad$ is the repayment rate (the inverse of the PD) of each bank

As can be seen from table I, the fall in interest rates causes a portfolio reallocation effect that leads them, in general, to adopt a slightly more conservative strategy which produces marginally lower profits, capital and capital adequacy ratio, but a higher repayment rate (lower probability of default, PD), for reasons set out below.

Banks in our model choose their optimal expected level of profitability by equating the derived marginal benefit with the corresponding marginal cost. On the one hand, higher profitability not only directly increases their utility but also raises their capital to asset ratios, allowing them to suffer less capital violation penalties. This latter source of marginal benefit is lower the higher the value of banks' risk-weighted assets. On the other hand, in order to achieve higher profitability, other things constant, they take more risk and therefore suffer higher cost in the form of higher expected default penalties. In the above comparative static exercise, since the default probability of all 
household borrowers decreases in both states, the corresponding values of every bank's risk-weighted assets increase. This leads all banks to revise the trade off between the relative marginal benefit and cost in such a way that they are willing to achieve a marginally lower level of profitability in both states, compared with the corresponding initial equilibrium value, in pursuit of suffering less default penalties ${ }^{9}$. Consequently, their capital declines slightly in both states compared with the initial equilibrium. This, together with the fact that the values of their risk-weighted assets increase, causes all banks to suffer greater capital violation penalties.

Given that banks operate under a perfectly competitive environment, they treat all interest rates and the households' default probability as given when making their optimal decisions. However, in response to shocks, these variables have to adjust endogenously to satisfy market clearing conditions, where the direction and extent of the adjustment depend on how banks and households adjust their portfolios. This 'portfolio reallocation' effect produces pressures on banks' profitability and their willingness to take risk $^{10}$. As for bank $\delta$ in both states and banks $\gamma$ and $\tau$ in the bad state, this portfolio reallocation effect is relatively weak, causing them to simply adopt a more conservative position in response to their lower targeted level of profitability. However, for banks $\gamma$ and $\tau$ in the good state, the portfolio reallocation effect produces a relatively strong negative pressure on their profitability so that they end up adopting a slightly riskier position in order to achieve their targeted level of profits.

\footnotetext{
${ }^{9}$ More precisely, higher risk-weighted assets in both states for all banks cause their marginal benefit of achieving higher profitability in terms of suffering less capital violation penalties to decrease. Given that the marginal benefit of achieving higher profitability is now lower than the corresponding marginal cost, they reduce their optimal desired level of profits.

${ }^{10}$ For example, a bank may respond to a positive shock by supplying more loans, thereby imposing a negative pressure on the lending rate. Similarly, the shock may cause household borrowers to demand more loans from such a bank, causing a positive crowding-out pressure on the lending rate. The relative strength of the pressures caused by the bank's and the borrower's portfolio adjustment depends in general on the relative elasticities of demand and supply in such a market.
} 
III (b) A withdrawal of deposits from bank $\delta$

We now come to the vital stage. We model the onset of a crisis as involving a withdrawal of funds (by wealthy Mr. $\Phi$ ) from a bank. This may be because Mr. $\Phi$ becomes an earlier consumer, following the line of analysis initiated by Diamond and Dybvig, (1983) and extended by Allen and Gale, (2007), or because he received information that bank $\delta$ has a higher PD, (is nearing insolvency).

In particular, we decrease the (log) autonomous deposit supply of Mr. $\Phi$ with bank $\delta$ by approximately $0.8 \%$.

Table II: \% changes in key variables given a positive deposit supply shock on bank $\delta$ (Central Bank sets its base money)

\begin{tabular}{|c|c|c|c|c|c|c|c|c|c|c|c|c|c|}
\hline & \multicolumn{3}{|c|}{ Interest Rates } & \multirow{2}{*}{$\pi_{i}^{b}$} & \multirow{2}{*}{$\pi_{i i}^{b}$} & \multirow{2}{*}{$e_{i}^{b}$} & \multirow{2}{*}{$e_{i i}^{b}$} & \multirow{2}{*}{$k_{i}^{b}$} & \multirow{2}{*}{$k_{i i}^{b}$} & \multirow{2}{*}{$v_{i}^{b}$} & \multirow{2}{*}{$v_{i i}^{b}$} & \multirow{2}{*}{$\mathrm{GDP}_{\mathrm{i}}$} & \multirow{2}{*}{$\mathrm{GDP}_{\mathrm{ii}}$} \\
\hline & $r_{d}^{b}$ & $r^{b}$ & $\rho$ & & & & & & & & & & \\
\hline $\operatorname{Bank} \delta$ & 2.7 & 2.9 & \multirow{3}{*}{2.3} & 0.03 & 0.04 & $\frac{3}{10^{3}}$ & $\frac{2}{10^{3}}$ & 0.8 & 0.9 & -0.03 & -0.03 & \multirow{3}{*}{-0.16} & \multirow{3}{*}{-0.16} \\
\hline Bank $\gamma$ & 2.3 & 3.2 & & 0.03 & 0.04 & $\frac{5}{10^{3}}$ & 0.02 & 0.4 & 0.5 & $\frac{6}{10^{3}}$ & $-\frac{9}{10^{3}}$ & & \\
\hline Bank $\tau$ & 2.3 & 3.1 & & $\frac{-2}{10^{3}}$ & $\frac{-2}{10^{3}}$ & $\frac{9}{10^{4}}$ & $\frac{9}{10^{4}}$ & 0.4 & 0.4 & $\frac{3}{10^{3}}$ & -0.01 & & \\
\hline
\end{tabular}

\begin{tabular}{|c|c|c|c|c|c|c|c|c|c|c|c|c|c|}
\hline \multicolumn{14}{|c|}{$\begin{array}{c}\text { Table III: \% changes in key variables given a positive deposit supply shock on } \\
\text { bank } \delta \text { (Central Bank sets the interbank rate) }\end{array}$} \\
\hline & \multicolumn{3}{|c|}{ InterestRates } & \multirow{2}{*}{$\pi_{i}^{b}$} & \multirow[b]{2}{*}{$\pi_{i i}^{b}$} & \multirow[b]{2}{*}{$e_{i}^{b}$} & \multirow[b]{2}{*}{$e_{i i}^{b}$} & \multirow[b]{2}{*}{$k_{i}^{b}$} & \multirow[b]{2}{*}{$k_{i i}^{b}$} & \multirow[b]{2}{*}{$v_{i}^{b}$} & \multirow[b]{2}{*}{$v_{i i}^{b}$} & \multirow{2}{*}{$\mathrm{GDP}_{\mathrm{i}}$} & \multirow[b]{2}{*}{$\mathrm{GDP}_{\mathrm{ii}}$} \\
\hline & $r_{d}^{b}$ & $r^{b}$ & $\rho$ & & & & & & & & & & \\
\hline Bank $\delta$ & $-\frac{4}{10^{3}}$ & 0.01 & \multirow{3}{*}{0.0} & 0.02 & 0.02 & $\frac{2}{10^{3}}$ & $\frac{1}{10^{3}}$ & 0.5 & 0.5 & $-\frac{8}{10^{3}}$ & $\frac{3}{10^{3}}$ & \multirow{3}{*}{$-\frac{3}{10^{4}}$} & \multirow{3}{*}{$-\frac{3}{10^{4}}$} \\
\hline Bank $\gamma$ & 0.0 & $\frac{3}{10^{3}}$ & & 0.0 & 0.0 & 0.0 & 0.0 & $\frac{8}{10^{4}}$ & $\frac{9}{10^{4}}$ & 0.0 & 0.0 & & \\
\hline Bank $\tau$ & 0.0 & $\frac{3}{10^{3}}$ & & 0.0 & 0.0 & 0.0 & 0.0 & $\frac{7}{10^{4}}$ & $\frac{8}{10^{4}}$ & 0.0 & 0.0 & & \\
\hline
\end{tabular}


As can be seen, a shock withdrawal of deposits from the banking system can cause havoc if the CB keeps the monetary base constant. Even the relatively small withdrawal $(0.8 \%$ from bank $\delta)$ causes lending rates to go up by about $3 \%$, (i.e. from about $6 \%$ to about $6.18 \%$ ), and causes a significant decline in GDP (in both states) of $0.16 \%$. If we consider, instead, serious crises in which the broad money stock may fall precipitously by 10 or $20 \%$, it become obvious that holding the monetary base constant endangers a CB's core purpose of maintaining systemic stability.

In sharp contrast a policy of maintaining nominal interest rates stable virtually defuses the risks attendant on sudden deposit withdrawals. Indeed, the only reason why there is any contagious effect at all is because bank $\delta$ was a lender in the interbank market. In this case, there is, in equilibrium, even with the interbank rate held constant, a very small reallocation of funds by bank $\delta$ away from bank loans with associated minimal increases in lending rates, (thereby causing a tiny increase in bank profits and capital; PD of bank $\delta$ also rises). If the withdrawal of funds had been from bank $\gamma$, a net borrower on the interbank market, in order to maintain a constant level of interbank rates, the withdrawal, by Mr. $\Phi$ from bank $\gamma$, would have had to be replaced one-forone by an equivalent injection of base money. Every item in the table would be a zero. The only change would be that a decline in deposits by $\Phi$ would be exactly replaced by extra deposits in the system by the $\mathrm{CB}$.

III (c) A sudden decline in bank capital to bank $\delta$ in the initial period

Yet another cause of crisis could arise from a sharp drop in a bank's capital base, perhaps arising from fraud, a rogue trader (Barings, Soc Gen), or the default of some 
large borrower. Again we examine whether the effects of this will differ dependent on the policy instrument adopted by the CB.

In this comparative static exercise, we decrease the capital endowment of bank $\delta$ in the initial period by approximately 5.6\%. As before, we first consider the case when the Bank sets its base money as its instrument (table IV). We observe that the directional responses of most of the variables are the same as the case when we assume that there is a negative deposit supply shock to bank $\delta$. This is because these two shocks both result in fewer available funds for bank $\delta$ to invest. However, the exception is the response of bank $\delta$ 's capital, and capital to asset ratios, in the second period. Unlike the case of the negative deposit supply shock, here we observe that bank $\delta$ 's capital position and its capital to adequacy ratios worsen quite sharply in both states of the world. The reason for this lies in the fact that a negative endowment shock imposes a direct negative effect on the capital of bank $\delta$ in the second period, thus increasing its capital requirements' violation penalty.

We now turn to analyse the effects of the same shock but this time under the assumption that the Bank fixes the interbank rate (table V). As in the case when there is a negative deposit supply shock to bank $\delta$ in state ii, we found in this case that the main contagion effects operate via the consumer loan default channel. However, the major difference is that here the effects of capital decline in bank $\delta$ produces beneficial contagion effects onto the rest of the banks in the banking sector. Recall that the Bank's sterilisation policy in the interbank market reduces the relative attractiveness of interbank investment, implying that bank $\delta$ responds to lower capital by reducing its investment in the interbank market. In this case, the extent of such 
decrease is so large that bank $\delta$ has to switch part of its investment into the loan market. This in turn provides some additional credit supply to the economy, lowering the probability of default in the consumer loan markets. This positive contagion effect raises the other two banks' expected return on their credit extension. Thus, they also extend more credit, causing the aggregate output to rise in both states. This in turn reduces the severity of credit crunch in the economic system even further. Moreover, unlike before, we observe that banks $\gamma$ and $\tau$ now violate 'more' their capital adequacy requirements and therefore suffer additional capital violation penalties. This is because a lower default probability of every household causes the values of banks $\gamma$ 's and $\tau$ 's risk-weighted assets to increase. In conclusion, we see that emergency liquidity assistance, when implemented under an interest rate targeting regime, may engender beneficial effects to financial stability

\begin{tabular}{|c|c|c|c|c|c|c|c|c|c|c|c|c|c|}
\hline \multicolumn{14}{|c|}{$\begin{array}{c}\text { Table IV: \% changes in key variables given a negative shock on } \\
\text { bank } \delta \text { 's capital at } t=1 \text { (Central Bank sets base money) }\end{array}$} \\
\hline & \multicolumn{3}{|c|}{ Interest Rates } & \multirow{2}{*}{$\pi_{i}^{b}$} & \multirow{2}{*}{$\pi_{i i}^{b}$} & \multirow{2}{*}{$e_{i}^{b}$} & \multirow{2}{*}{$e_{i i}^{b}$} & \multirow{2}{*}{$k_{i}^{b}$} & \multirow{2}{*}{$k_{i i}^{b}$} & \multirow{2}{*}{$v_{i}^{b}$} & \multirow{2}{*}{$v_{i i}^{b}$} & \multirow[b]{2}{*}{$\mathrm{GDP}_{\mathrm{i}}$} & \multirow[b]{2}{*}{$\mathrm{GDP}_{\mathrm{ii}}$} \\
\hline & $r_{d}^{b}$ & $r^{b}$ & $\rho$ & & & & & & & & & & \\
\hline $\operatorname{Bank} \delta$ & 0.9 & 0.9 & \multirow{3}{*}{0.8} & 0.01 & 0.01 & -5.1 & -5.8 & -4.9 & -5.5 & -0.03 & $-\frac{5}{10^{3}}$ & \multirow{3}{*}{-0.05} & \multirow{3}{*}{-0.05} \\
\hline Bank $\gamma$ & 0.8 & 1 & & $\frac{9}{10^{3}}$ & 0.01 & $\frac{2}{10^{3}}$ & $\frac{5}{10^{3}}$ & 0.1 & 0.2 & $\frac{2}{10^{3}}$ & $-\frac{3}{10^{3}}$ & & \\
\hline $\operatorname{Bank} \tau$ & 0.8 & 1 & & $\frac{2}{10^{3}}$ & $\frac{2}{10^{3}}$ & $\frac{3}{10^{4}}$ & $\frac{3}{10^{4}}$ & 0.1 & 0.1 & $\frac{1}{10^{3}}$ & $-\frac{4}{10^{3}}$ & & \\
\hline
\end{tabular}

\begin{tabular}{|c|c|c|c|c|c|c|c|c|c|c|c|c|c|}
\hline \multicolumn{14}{|c|}{$\begin{array}{l}\text { Table V: \% changes in key variables given a negative shock on } \\
\text { bank } \delta \text { 's capital at } t=1 \text { (Central Bank sets the interbank rate) }\end{array}$} \\
\hline & $\operatorname{Int}$ & rest $\mathrm{R}$ & & & & & & & & & & & \\
\hline & $r_{d}^{b}$ & $r^{b}$ & $\rho$ & $\pi_{i}^{D}$ & $\pi_{i i}^{b}$ & $e_{i}^{D}$ & $e_{i i}^{b}$ & $k_{i}^{D}$ & $k_{i i}^{b}$ & $v_{i}^{b}$ & $v_{i i}^{D}$ & $\mathrm{GDP}_{\mathrm{i}}$ & $\mathrm{GDP}_{\mathrm{ii}}$ \\
\hline Bank $\delta$ & 0.02 & -0.05 & \multirow{3}{*}{0.0} & $\frac{6}{10^{3}}$ & $\frac{7}{10^{3}}$ & -5.1 & -5.8 & -5.0 & -5.7 & -0.03 & $\frac{5}{10^{3}}$ & \multirow{3}{*}{$\frac{2}{10^{3}}$} & \multirow{3}{*}{$\frac{2}{10^{3}}$} \\
\hline Bank $\gamma$ & 0.0 & -0.02 & & 0.0 & 0.0 & 0.0 & 0.0 & $-\frac{4}{10^{3}}$ & $-\frac{4}{10^{3}}$ & 0.0 & 0.0 & & \\
\hline $\operatorname{Bank} \tau$ & 0.0 & -0.02 & & 0.0 & 0.0 & 0.0 & 0.0 & $-\frac{3}{10^{3}}$ & $-\frac{4}{10^{3}}$ & 0.0 & 0.0 & & \\
\hline
\end{tabular}


Once again, the offset provided by CB injections of liquidity, (to offset bank $\delta$ 's capital impairment), largely removes the contagious effect operating through interest rates and the interbank market. The impact on GDP is not only vastly smaller than in the case of a constant monetary base; it is even marginally in the opposite direction. There is, however, one tiny reverse effect. When interest rates rise, (following bank $\delta$ 's problems) it increases the profitability, capital and CAR of the other, unaffected banks. They become stronger. This beneficial effect on them is lost when the CB stabilizes interest rates. Although all the contagion effects which operate through the interbank rate channel are completely sterilised when the CB's instrument is the interbank rate, such a policy could also affect the extent of contagion via other routes.

III (d) A tighter regulatory policy in the guise of higher capital adequacy violation penalties in the bad state, (state ii)

Let the regulator increase the capital violation penalties for all banks in the bad state from 0.1 to 0.12 (approximately $20 \%$ ). We summarise the percentage changes of some of the key variables in response to such shock in table VI, initially when the CB holds base money constant, and in table VII, when the CB holds interbank interest rates constant. 


\begin{tabular}{|c|c|c|c|c|c|c|c|c|c|c|c|c|c|}
\hline \multicolumn{14}{|c|}{$\begin{array}{c}\text { Table VI: \% changes in key variables given a rise in default penalty for } \\
\text { all banks in state } i i \text { (Central Bank sets base money) }\end{array}$} \\
\hline & Inte & est R & & & & & & & & & & & \\
\hline & $r_{d}^{b}$ & $r^{b}$ & $\rho$ & $\pi_{i}^{D}$ & $\pi_{i i}^{b}$ & $e_{i}^{D}$ & $e_{i i}^{b}$ & $k_{i}^{b}$ & $k_{i i}^{b}$ & $v_{i}^{b}$ & $v_{i i}^{b}$ & $\mathrm{GDP}_{\mathrm{i}}$ & $\mathrm{GDP}_{\mathrm{ii}}$ \\
\hline Bank $\delta$ & -0.3 & -0.3 & \multirow{3}{*}{0.4} & $-\frac{3}{10^{4}}$ & 20.9 & $-\frac{3}{10^{5}}$ & 0.8 & $-\frac{9}{10^{3}}$ & 0.8 & $-\frac{3}{10^{3}}$ & -0.1 & \multirow{3}{*}{$\frac{3}{10^{3}}$} & \multirow{3}{*}{$\frac{3}{10^{3}}$} \\
\hline Bank $\gamma$ & 0.4 & 0.08 & & $-\frac{1}{10^{4}}$ & 21.6 & $-\frac{2}{10^{5}}$ & 9.4 & $-\frac{2}{10^{3}}$ & 9.4 & $-\frac{8}{10^{3}}$ & -0.6 & & \\
\hline Bank $\tau$ & 0.4 & 0.08 & & $-\frac{2}{10^{5}}$ & 20.2 & $-\frac{3}{10^{6}}$ & 3.3 & $-\frac{2}{10^{3}}$ & 3.3 & $-\frac{9}{10^{3}}$ & 0.3 & & \\
\hline
\end{tabular}

Table VII: \% changes in key variables given a rise in default penalty for all banks in state $i i$ (Central Bank sets the interbank rate)

\begin{tabular}{|c|c|c|c|c|c|c|c|c|c|c|c|c|c|}
\hline & \multicolumn{3}{|c|}{ Interest rates } & & & & & & & & & & \\
\hline & $\tau_{\mathrm{d}}$ & $\tau$ & $\rho$ & $\pi_{\mathrm{i}}$ & $\pi_{\mathrm{ii}}$ & $e_{i}$ & $\mathrm{e}_{\mathrm{ii}}$ & $\mathrm{k}_{\mathrm{i}}$ & $\mathrm{k}_{\mathrm{ii}}$ & $\mathrm{v}_{\mathrm{i}}$ & $\mathrm{v}_{\mathrm{ii}}$ & $\mathrm{GDP}_{\mathrm{i}}$ & GDP $_{\text {ii }}$ \\
\hline Bank $\delta$ & -0.01 & $7 / 10^{3}$ & & 0 & 0.9 & 0 & 0.04 & $1 / 10^{4}$ & 0.04 & $6 / 10^{4}$ & & \multirow{3}{*}{$-4 / 10^{3}$} & \multirow{3}{*}{$-5 / 10^{4}$} \\
\hline Bank $\gamma$ & 0 & .01 & 0 & 0 & 1.6 & 0 & 0.7 & $1 / 10^{4}$ & 0.7 & $5 / 10^{4}$ & -0.05 & & \\
\hline Bank $\tau$ & 0 & $7 / 10^{3}$ & & 0 & 0.2 & 0 & 0.04 & $1 / 10^{4}$ & 0.04 & $1 / 10^{4}$ & & & \\
\hline
\end{tabular}

Since violating capital requirement in state ii is now more costly for all banks, in response, they engage in the following actions in an attempt to increase the values of their capital to asset ratios in the bad state. First, they choose to increase their optimal profitability level in this particular state by adopting a riskier position. The higher profitability, other things constant, improves their capital position in the bad state, allowing them ultimately to suffer fewer capital violation penalties. Second, banks $\gamma$ and $\delta$ adjust their portfolios such that the size of their risk-weighted assets in the bad state decreases, thereby alleviating the extent of their capital requirements' violation even further. For bank $\gamma$, it reduces its overall investment by demanding less funds, both from the deposit and interbank markets, and invests less in the loan market. This causes both the interbank rate and its deposit rate to decrease and its lending rate to increase. Consequently, Mr. $\varphi$ supplies less deposits with bank $\gamma$ and Mr. $\alpha$ demands less funds from bank $\gamma$. Bank $\delta$ also demands less funds from the deposit market, causing its deposit rate to fall and Mr. $\varphi$ to supply less deposits with bank $\delta$. 
Moreover, it reduces its investment both in the loan and interbank markets. The extent of decline in bank $\delta$ 's interbank investment is further aggravated since the interbank rate is now lower. Because bank $\delta$ 's action produces an upward pressure on its lending rate, Mr. $\beta$ demands less consumer loans.

Even though a higher capital violation penalty in state ii produces an upward pressure on the cost of extending more credit for bank $\tau$, such a pressure is marginally outweighed by the negative pressure arising from a cheaper cost of interbank borrowing. Thus, bank $\tau$ borrows less from the deposit market, switches to borrowing more from the interbank market, and extends slightly more loans to Mr. $\theta$. Thus, both its deposit and lending rates decrease by $0.006 \%$ and $0.001 \%$, respectively.

Because the extent of decrease in credit extension by banks $\gamma$ and $\delta$ over-compensates the extent of increase in the credit supply of bank $\tau$, the aggregate supply of credit in the economy decreases. This causes GDP to decline in both states (i.e. by $0.0008 \%$ in both states), which in turn results in a higher default probability of every household.

One of the main features of the portfolio adjustment is that the increase in CAR penalties causes the banks to adopt a more conservative strategy, involving smaller extensions of loans and deposits, thereby putting downwards pressures on interest rates. When the $\mathrm{CB}$ holds interest rates constant instead these latter effects are sterilised, thus bringing about, in equilibrium slightly more loans, and a lesser decline in GDP at the expense of slightly lower profits and CAR (in state (i)).

But the differences in this instance are marginal. 
III (e) A bad, negative shock to GDP in the bad state, (state ii)

Our final comparative static exercise involves an assessment of a negative shock in the autonomous component of GDP in the bad state. Table VIII summarises certain key results when the monetary base is held constant.

\begin{tabular}{|c|c|c|c|c|c|c|c|c|c|c|c|c|c|}
\hline \multicolumn{14}{|c|}{$\begin{array}{l}\text { Table VIII: \% changes in key variables given a decline in GDP in the bad state } \\
\text { (Central Bank sets base money) }\end{array}$} \\
\hline & \multicolumn{3}{|c|}{ Interest Rates } & \multirow{2}{*}{$\pi_{i}^{b}$} & \multirow[b]{2}{*}{$\pi_{i i}^{b}$} & \multirow[b]{2}{*}{$e_{i}^{b}$} & \multirow{2}{*}{$e_{i i}^{b}$} & \multirow[b]{2}{*}{$k_{i}^{b}$} & \multirow{2}{*}{$k_{i i}^{b}$} & \multirow{2}{*}{$v_{i}^{b}$} & \multirow[b]{2}{*}{$v_{i i}^{b}$} & \multirow[b]{2}{*}{$\mathrm{GDP}_{\mathrm{i}}$} & \multirow[b]{2}{*}{$\mathrm{GDP}_{\mathrm{ii}}$} \\
\hline & $r_{d}^{b}$ & $r^{b}$ & $\rho$ & & & & & & & & & & \\
\hline Bank $\delta$ & -2.4 & -1.1 & \multirow{3}{*}{-1} & $\frac{4}{10^{3}}$ & $\frac{9}{10^{3}}$ & $\frac{4}{10^{3}}$ & $\frac{4}{10^{4}}$ & 0.1 & 0.2 & 0.02 & -0.06 & \multirow{3}{*}{-0.01} & \multirow{3}{*}{-2.03} \\
\hline Bank $\gamma$ & -2 & -1.1 & & $\frac{7}{10^{3}}$ & 0.02 & $\frac{1}{10^{3}}$ & $\frac{7}{10^{3}}$ & 0.1 & 0.2 & $-\frac{1}{10^{3}}$ & $-\frac{1}{10^{3}}$ & & \\
\hline $\operatorname{Bank} \tau$ & -2 & -1.1 & & $\frac{1}{10^{3}}$ & $\frac{2}{10^{3}}$ & $\frac{2}{10^{3}}$ & $\frac{4}{10^{4}}$ & 0.1 & 0.2 & $\frac{1}{10^{3}}$ & -0.1 & & \\
\hline
\end{tabular}

Table IX: \% changes in key variables given a decline in GDP in the bad state (Central Bank sets the interbank rate)

\begin{tabular}{|c|c|c|c|c|c|c|c|c|c|c|c|c|c|}
\hline & \multicolumn{13}{|c|}{ Interest rates } \\
\hline & $\mathrm{T}_{\mathrm{d}}$ & $\tau$ & $\mathrm{P}$ & $\pi_{\mathrm{i}}$ & $\pi_{\mathrm{ii}}$ & $\mathrm{e}_{\mathrm{i}}$ & $\overline{\mathrm{e}_{\mathrm{ii}}}$ & $\mathrm{k}_{\mathrm{i}}$ & $\mathrm{k}_{\mathrm{ii}}$ & $\mathrm{v}_{\mathrm{i}}$ & $\mathrm{V}_{\mathrm{ii}}$ & $\mathrm{GDP}_{\mathrm{i}}$ & $\mathrm{GDP}_{\mathrm{ii}}$ \\
\hline Bank $\delta$ & -0.06 & .01 & & .01 & -0.2 & $1 / 10^{4}$ & 0 & 3.8 & 4.9 & $5 / 10^{3}$ & -.84 & & \\
\hline Bank $\gamma$ & 0 & .16 & 0 & .03 & .05 & $5 / 10^{4}$ & 0.02 & 4.9 & 6.3 & $4 / 10^{3}$ & -1.1 & -0.02 & -2.18 \\
\hline Bank $\tau$ & 0 & .16 & & .05 & .07 & $1 / 10^{4}$ & $1 / 10^{4}$ & 4.6 & 5.8 & $4 / 10^{3}$ & -1.0 & & \\
\hline
\end{tabular}

The shock directly reduces the expected aggregate output in the second period. This simultaneously lowers all individual borrowers' demand for loans, and the probability that they will repay their loans in full, as well as reducing Mr. $\varphi$ 's supply of deposits with every bank. Given a lower loan demand by Mr. $\alpha$ and $\theta$, the lending rates offered by their respective nature-selected banks $(\gamma$ and $\tau$ ) reduces by $1.1 \%$. Moreover, an increase in the default probability of Mr. $\alpha$ and $\theta$ further worsens the expected rates of return on credit extension for banks $\gamma$ and $\tau$. Thus, these banks supply less credit, and demand fewer funds from both the deposit and interbank markets. Even though Mr. 
$\varphi$ 's decision to deposit less with these banks imposes a positive pressure on banks $\gamma$ 's and $\tau$ 's deposit rates, such a pressure is relatively weak when compared to the negative effect from these banks' smaller demand for deposits. Thus, we observe that the interbank rate and the deposit rates offered by the two banks fall.

For the same reason as banks $\gamma$ and $\tau$, bank $\delta$ supplies fewer loans to Mr. $\beta$. Unlike the other two banks, however, bank $\delta$ is the net lender in the interbank market. So, it responds to a lower interbank rate by investing less in the interbank market. Since its investment has fallen, bank $\delta$ demands less funds from the deposit market, reducing its deposit rate by $2.4 \%$.

As mentioned, the initial shock directly reduces the probability that an individual household will repay her loans in full. The extent of such decrease is further magnified since the overall credit supply in the economy and the aggregate output in both states falls ${ }^{11}$.

Consequently, the values of all banks' risk-weighted assets falls. This in turn implies that the marginal benefit of higher profitability in terms of suffering less capital violation penalties for all banks is greater. Thus, banks revise their optimal level of profits upwards in order to suffer lower default penalties. This directly improves their capital position. Given higher profitability, bank $\gamma$ adopts a less conservative position in both states. The same is true for banks $\delta$ and $\tau$ in the bad state. However, the positive portfolio reallocation effect on banks $\delta$ 's and $\tau$ 's profitability in the good state

\footnotetext{
${ }^{11}$ As can be seen from table VIII, GDP in the bad state falls by $2.03 \%, 2.02 \%$ of which is from the direct effect and $0.01 \%$ of which is from the indirect effect via lower aggregate supply of credit in the economy.
} 
is so strong that they can adopt a more conservative position and still achieve the targeted profitability level

In this case the negative shock to GDP is mitigated by the decline in interest rates. This is prevented when the CB pegs interest rates. This is, of course, our equivalent to the Sargent and Wallace case, that an (unforeseen) shock to the economy is quasiautomatically better stabilised by holding $\mathrm{M}$ constant than by pegging the interest rate.

Thus the results of the shock on GDP are amplified, as shown above in table IX. Nevertheless the higher interest rates do have a slightly offsetting effect in strengthening bank profits, capital and CARs. Against this, the less conservative bank strategy, induced by higher interest rates, leads to a significantly worse (lower) repayment rate in state (ii) (higher PD) than when the monetary base was held constant

\section{A Caveat and Qualification}

In this model there is only one market rate, the interbank rate. An extension to the model will be to introduce additional financial markets, e.g. for longer-dated bonds. This latter, longer-dated, market will generally, be riskier than the interbank market, if only because the longer duration asset will be subject to more market risk. In crises when risk aversion increases, there will normally be a shift in demand away from the less liquid, riskier asset to the safer asset. Risk premia will increase. So a panic may lead to increased demand, and falling interest rates, on short-dated, safe assets while riskier longer dated assets fall in price (rising yield). In such cases a $\mathrm{CB}$, whose 
operational practice is to peg interest rates, (between regular MPC meeting dates), might be led unwittingly to tighten policy at the wrong time. Moreover, such a crisis could lead to expectations of future price levels being revised down, so that a given level of nominal rates becomes a rising level of real interest rates.

Recall, however, that the choice of operational instrument only requires such a peg to be maintained between the regular occasions (of MPC meetings) to review and to decide on the appropriate policy stance. The onset of a financial crisis could, should lead to such a meeting being advanced in time, (as in the case of the inter-meeting decision of the FOMC to cut interest rates during the LTCM/US Treasury bond crisis in 1998, and in a couple of cases in 2007/8). Moreover, such a crisis will often be accompanied by deposit withdrawals and a flight to cash, (or foreign currencies). So an operational policy to peg interest rates, between MPC decision meetings, is still likely to be far preferable, as a means of sustaining systemic stability, to a policy of holding the monetary base constant.

The next stage of our research on systemic stability will involve the inclusion of additional asset market(s) in the model, partly to examine and to analyse issues relating to (time-varying) liquidity preference. No doubt that will complicate the analysis somewhat. But we conjecture that our conclusion, that Central Banks have good reason to behave as they have traditionally done, to hold interest rates, not the monetary base, pegged between decision-making meetings, will continue to hold. 


\section{V. $\underline{\text { Conclusions }}$}

Almost without exception central banks have chosen to set a nominal (short-term) interest rate, (rather than the amount of the monetary base), as their operational instrument, despite there being occasional academic argument that the reverse would be better. One reason for this choice is that it helps to stabilize the financial and banking systems, as demonstrated here. Indeed the Federal Reserve System was founded precisely in order to provide an 'elastic currency'. Thus interest rates should be held stable in response to temporary shocks to liquidity demands, e.g. due to seasonal factors and fluctuations in market confidence, and let the monetary base adjust, rather than vice versa. As Miron (1986 and 1996) has shown, prior to 1913 there were marked seasonal fluctuations in interest rates in the USA, and crises tended to occur most often at times of seasonal stress, in October when moving the crops (also see Goodhart, 1969).

A central bank aims to avoid two main risks, the risk of price instability and the risk of financial instability. The speed (frequency) with which the latter may occur is generally much higher, and its onset less easily observable/measurable. So a policy choice which allows interest rates to be re-set at discrete, occasional intervals, often in the context of a medium-term forecast, should not impair the achievement of an inflation target, so long as the Monetary Policy Committee's reaction function is appropriately designed. In the meantime, with interest rates thus pegged, the monetary base can adjust quasi-automatically to offset (sometimes unobservable) shocks to the demand for money. It is a matter of achieving the correct time frame for monetary policy. 
Bibliography

Allen, F. and D. Gale, (2007), Understanding Financial Crises, (Oxford, UK: Oxford University Press).

Aspachs, O., Goodhart, C.A.E., Tsomocos, D.P. and L. Zicchino, (2007), 'Towards a Measure of Financial Fragility', Annals of Finance, 3, (1), 37-74, (January).

Aspachs, O., Goodhart, C.A.E., Segoviano, M., Tsomocos, D.P. and L. Zicchino, (2006 ), "Searching for a Metric for Financial Stability", (with O. Aspacs, C.A.E. Goodhart, M. Segoviano and L. Zicchino), LSE FMG Special Paper No 167.

Bhattacharya, S., Goodhart, C.A.E., Sunirand, P. and D.P.Tsomocos, (2007), "Banks, Relative Performance, and Sequential Contagion”, Economic Theory, v. 32, Nr. 2, pp 381-398.

Diamond, D. and P. Dybvig, (1983), 'Bank Runs, Deposit Insurance, and Liquidity', Journal of Political Economy, 91 (3), (June), 401-419.

Gaspar, V., (2006), 'Bagehot and Coase meet the Single European Market', Paper in progress, draft October 31.

Goodhart, C.A.E., (1969), The New York Money Market and the Finance of Trade, Harvard Economic Studies, Vol. 132, (Harvard University Press: Cambridge, Mass).

Goodhart, C.A.E., Sunirand, P. and D.P. Tsomocos, (2004), 'A Model to Analyse Financial Fragility: Applications', Journal of Financial Stability, 1, 1-30.

Goodhart, C.A.E., Sunirand, P. and D.P. Tsomocos, (2005), 'A Risk Assessment Model for Banks', Annals of Finance, 1, 197-224.

Goodhart, C.A.E., Sunirand, P. and D.P. Tsomocos, (2006a), 'A Model to Analyse Financial Fragility', Economic Theory, 27, 107-142.

Goodhart, C.A.E., Sunirand, P. and D.P. Tsomocos, (2006b), 'A Time Series Analysis of Financial Fragility in the UK Banking System', Annals of Finance, 2, 1-21.

Goodhart, C.A.E. and L. Zicchino, (2005), 'A Model to Analyse Financial Fragility', Bank of England Financial Stability Review, June, pp 106-115.

McCallum, B.T., (1999), 'Recent Developments in the Analysis of Monetary Policy Rules', Federal Reserve Bank of St Louis Review, 81, (6), 3-12, (November/December).

McCallum, B.T., (2005), 'What have we Learned since October 1979', Federal Reserve Bank of St Louis Review, 87, (2), 287-291, (March/April).

Miron, J.A., (1986), 'Financial Panics, the Seasonality of the Nominal Interest Rate, and the Founding of the Fed', American Economic Review, 76 (1), (March), 125-140. 
Miron, J.A., (1996), The Economics of Seasonal Cycles, (Cambridge, Mass: MIT Press).

Poole, W., (1970), 'Optimal Choice of Monetary Policy Instruments in a Simple Stochastic Macro Model', Quarterly Journal of Economics, 84, 197-216, (May).

Robertson, D.H., (1959), 'The Trade Cycle: Models and Tools' in Lectures on Economic Principles, (London: Staples Press).

Sargent, T.J. and N. Wallace, (1975), "Rational” Expectations, the Optimal Monetary Instrument, and the Optimal Money Supply Rule', Journal of Political Economy, 83, (2), 241-254.

Shubik, M and Tsomocos, D P (1992), 'A strategic market game with a mutual bank with fractional reserves and redemption in gold', Journal of Economics, Vol. 55 (2), pages 123-50.

Shubik, M and Wilson, C (1977), 'The optimal bankruptcy rule in a trading economy using fiat money', Journal of Economics, Vol. 37, pages 337-54.

Tsomocos, D.P., (2003), "Equilibrium Analysis, Banking, and Financial Instability", Journal of Mathematical Economics, Volume 39, Issues 5-6, pp. 619-655.

Tsomocos, D.P., (2003), "Equilibrium Analysis, Banking, Contagion and Financial Fragility", Bank of England W.P. Series \#175. (Also, Greek Economic Review, Volume 23(1), 2004).

Woodford, M., (2006), Paper presented at ECB Conference, Frankfurt, November $9 / 10$. 